\title{
International mergers and trade liberalisation: implications for unionised labour
}

\author{
Odd Rune Straume \\ Department of Economics, University of Bergen, Fosswinckelsgt. 6, N-5007 Bergen, Norway
}

Received 16 March 2001; received in revised form 8 March 2002; accepted 2 August 2002

\begin{abstract}
An international oligopoly model with unionised and non-unionised firms is constructed to make predictions about the pattern of international mergers. Applying the method of endogenous merger formation developed by Horn and Persson [International Journal of Industrial Organisation 19 (2001) 1213] we find that the equilibrium market structure is highly dependent on the level of trade costs. The model is further utilised to analyse the implications of trade liberalisation for unionised labour. A main finding is that, for sufficiently high levels of trade costs, unionised workers may benefit from a merger between non-unionised firms, whereas low levels of trade costs make unionised firms highly 'vulnerable' to an international merger, which could be detrimental to the union's ability to capture oligopoly rents.

(C) 2002 Elsevier Science B.V. All rights reserved.
\end{abstract}

JEL classification: F23; J51; L13

Keywords: International mergers; Union wages; Trade liberalisation

\section{Introduction}

Casual observation suggests that the phenomenon of international corporate mergers seems to be an increasingly important aspect of industrial organisation in most advanced countries. This view is also supported by empirical facts.

E-mail address: odd.straume@econ.uib.no (O.R. Straume). 
According to UNCTAD (2000), the total value of completed cross-border mergers and acquisitions (M\&A) rose from less than $\$ 100$ billion in 1987 to $\$ 720$ billion in 1999. Furthermore, in 1999, the share of all M\&A, in terms of value, that was cross-border reached nearly 31 percent. In the same year, international M\&A accounted for over 80 percent of total foreign direct investments (FDI).

From a theoretical point of view, international M\&A exhibit some features that are not fully explained by traditional merger analysis. It is possible to point out at least two specific aspects that could motivate international mergers. Most well known is probably the 'tariff jumping' motive, which is intuitively appealing: by forming a multinational firm, the merger participants are able to serve more markets without incurring any trade costs. This argument has received a lot of attention in the relatively rich literature on FDI and multinational enterprises (MNE), but hardly ever in the context of M\&A. ${ }^{2}$

Another phenomenon that could motivate international M\&A is the existence of strong trade unions. Lommerud et al. (2001b) suggest that international mergers could have a potentially strong disciplinary effect on union wage demands. If an internationally merged firm is able costlessly to shift production between plants in different markets, trade unions will likely be willing to reduce wage demands in order to prevent production being shifted abroad. ${ }^{3}$

The main purpose of the present paper is to explore these two different motives for international horizontal M\&A within a single model. ${ }^{4}$ Despite the obvious empirical importance of international merger formation, the amount of theoretical work on this subject is surprisingly scant. There are, however, a couple of notable exceptions. Horn and Persson (2001b) explore the incentives for national versus international mergers in a two-country reciprocal dumping model, whereas Head and Ries (1997) analyse possible welfare implications of international mergers, focusing on national versus supranational merger regulation. Neither of these papers considers the role of trade unions.

As a framework for analysing international M\&A, we choose a three-country/ three-firm model with Cournot competition in homogeneous goods and segmented markets. The model is quite similar to Fisher and Wright (1999), and is basically a straightforward extension of the reciprocal dumping model introduced by Brander (1981) and Brander and Krugman (1983). The role of trade unions in international M\&A is introduced by assuming a unionised labour market in one of the countries. This asymmetric feature of the model also allows us to capture the empirical

\footnotetext{
${ }^{1}$ See Markusen (1995) for an overview of the literature in this field.

${ }^{2}$ A noteworthy exception is Horn and Persson (2001b).

${ }^{3}$ An empirical example of firms' use of inter-plant rivalry to discipline trade unions is reported in Rasmusen (2001, pp. 190-194).

${ }^{4}$ The empirical importance of cross-border horizontal merger is confirmed by the fact that about 70 percent of all international M\&A in 1999 were horizontal (UNCTAD, 2000).
} 
observation that labour market structures seem to differ a great deal between otherwise similar countries.

Analysing the incentives for merger within this framework involves not only whether or not a merger is profitable, but also what type of merger is most likely to be carried out. In making such predictions we utilise an approach for endogenous merger formation developed by Horn and Persson (2001a), which is based on cooperative game theory. In the case of a symmetric trade cost structure the model always predicts some type of merger as the equilibrium outcome. We find that a merger between non-unionised firms is the equilibrium ownership structure $(E O S)$ if trade costs are above a certain level, whereas a merger involving the unionised firm is the EOS for sufficiently low levels of trade costs. An important feature of the model is that the presence of trade costs is a source of protection for unionised labour in an international oligopoly industry. The size of the trade costs will thus influence the union's optimal wage demand as a response to a merger, and this, in turn, plays a crucial role in determining the pattern of mergers.

The present model is also well suited to make a contribution to the ongoing debate about the effects of trade liberalisation for unionised labour. A sizable body of theoretical studies on this particular topic has emerged during the last decade, including Driffill and van der Ploeg (1993, 1995), Huizinga (1993), Danthine and Hunt (1994), Sørensen (1994) and Straume (2002). An important paper in this respect is Naylor (1998), who analyses the effects of trade liberalisation within the context of a unionised international duopoly. Naylor finds, perhaps somewhat counter-intuitively, that from an initial situation of intra-industry trade, a reduction of trade costs will increase union wages. This result suggests that trade liberalisation does not necessarily represent a threat to unionised labour. However, Naylor assumes that a firm can only supply a foreign market through exports. Considering the empirical importance of FDI this seems to be a rather restrictive assumption. Lommerud et al. (2001a) relax this assumption by considering greenfield FDI as an alternative for the unionised firm in an asymmetric international duopoly. This opens up the, perhaps more intuitively appealing, possibility that trade liberalisation can be seriously detrimental to unionised labour.

By considering international M\&A, which are empirically the most dominant form of FDI, as an alternative way to serve a foreign market, the present model offers some predictions that are more in line with Lommerud et al. Trade liberalisation can be both beneficial and detrimental to unionised labour, depending on the equilibrium ownership structure, but for very low levels of trade costs, international M\&A turn out to be an effective way to destroy union power.

Although there are some similar mechanisms at work whether FDI is greenfield or occurs as M\&A, the present paper differs from the analysis in Lommerud et al. in several ways. For instance, by considering FDI by merger, we are able to capture an important effect of economic integration and industrial restructuring, 
namely that trade unions can benefit from trade liberalisation through positive externalities from mergers between non-unionised firms.

The remainder of the paper is organised in the following way. Section 2 presents the basic ingredients of the model. In Section 3 we derive the optimal union strategies in each of the possible market structures for very general assumptions about the trade cost structure. Section 4 outlines the assumptions of the merger formation process. In Section 5 we derive the equilibrium outcome of the merger process under the assumption of a symmetric trade cost structure. Some concluding remarks are offered in Section 6.

\section{Model}

Consider an international oligopoly industry with three firms (owners), each located in a different country (market). We assume that entry to the industry is restricted, due to some firm-specific ownership advantages of the incumbents. The firms produce an homogeneous good $x$ under constant returns to labour input. Output per worker is normalised to unity, so that marginal cost for firm $i$ is given by the wage $w_{i}$. The industry is assumed to be symmetric in terms of market demand, but not necessarily in terms of trade costs. The trade costs associated with shipping a unit of $x$ between country $i$ and country $j$ are given by $t_{i j}$, and are exogenous. Furthermore, we assume that $t_{i j}=t_{j i}$. In principle, these trade costs can include both tariff and non-tariff cost components.

We adopt the segmented market hypothesis, where the firms compete in Cournot fashion, maximising profits by choosing sales in each market independently. Output produced in country $i$ and sold in market $j$ is denoted $x_{i j}$. Demand is assumed to be linear, with the inverse demand function in market $i$ given by

$$
p_{i}=1-\sum_{j=1}^{3} x_{j i}
$$

In each country there is, in addition, a perfectly competitive sector where workers can earn the competitive wage $\bar{w}$, assumed to be equal in all countries. The oligopoly industry is also asymmetric in the sense that the firm in country 1 is unionised, whereas the other firms are not. The union in country 1 is then able to capture some of the oligopoly rents by enforcing a wage above the competitive level. Those workers who are not able to find a 'good job' in the imperfectly competitive sector are employed in the competitive sector at wage $\bar{w}$.

It is reasonable to assume that the trade union cares about both wages and the available number of good jobs. This is most easily captured by assuming that the union aims to maximise union rents. Hence, the utility function of the union can be written as 


$$
U=\left(w_{1}-\bar{w}\right)\left(x_{11}+x_{12}+x_{13}\right),
$$

where $w_{1}$ is the union wage level.

We then make the simplifying assumption that the union unilaterally chooses the wage at a stage prior to the Cournot game. This corresponds to the monopoly union model, which, in the context of the generalised Nash bargaining solution, amounts to giving the union all the bargaining power and restricting bargaining to the wage alone. For simplicity, the competitive wage $\bar{w}$ will henceforth be set equal to zero.

We also assume that trade costs are always sufficiently low for intra-industry trade to occur between non-unionised firms. In the present model this means that we will restrict attention to the case of $t_{i j} \leqslant 1 / 2$.

The game is played in three stages. In the first stage the owners decide on the formation of the firms. In the second stage the union sets the wage for firm 1, and the firms then engage in Cournot competition in the last stage of the game.

\section{Market structures and union strategies}

In making predictions about equilibrium market structures in this model we want to exclude the possibility of complete monopolisation. This is not only a less interesting industry structure, but probably also a less relevant structure. It seems reasonable to assume, as Horn and Persson (2001b) do in a similar type of model, that a complete monopolisation would not be permitted by competition authorities.

Given the asymmetric nature of the model, we are still left with several possible market structures that could arise in equilibrium. To introduce some notation regarding the identification of different market structures, let the set of owners be given by $N=\{1,2,3\}$. Further, let an ownership structure $M_{i}$ be a partition of the set $N$ of owners into coalitions. We can then identify three categories of market structures, with a combined total of four possible ownership structures, which we choose to denote in the following way:

1. The fully decentralised structure: $M_{0}=\{1,2,3\}$.

2. A duopoly with a merger between the non-unionised firms: $M_{2+3}=\{1,(2+$ $3)\}$.

3. A duopoly with a merger involving the unionised firm: $M_{1+2}=\{(1+2), 3\}$ and $M_{1+3}=\{(1+3), 2\}$.

An important feature of each of these market structures is that the pattern of trade in each structure is endogenously determined by trade union behaviour. By altering its wage demand, the union is able to induce different patterns of trade and, as we will see, the optimal wage strategy of the trade union is crucially dependent on the trade cost structure of the industry. 


\subsection{The decentralised industry structure}

In $M_{0}$, the firms are faced with the following problems in the Cournot game:

$$
\begin{aligned}
& \max _{x_{11}, x_{12}, x_{13}} \pi_{1}=\left(p_{1}-w_{1}\right) x_{11}+\left(p_{2}-w_{1}-t_{12}\right) x_{12}+\left(p_{3}-w_{1}-t_{13}\right) x_{13}, \\
& \max _{x_{21}, x_{22}, x_{23}} \pi_{2}=\left(p_{1}-\bar{w}-t_{12}\right) x_{21}+\left(p_{2}-\bar{w}\right) x_{22}+\left(p_{3}-\bar{w}-t_{23}\right) x_{23}, \\
& \max _{x_{31}, x_{32}, x_{33}} \pi_{2}=\left(p_{1}-\bar{w}-t_{13}\right) x_{31}+\left(p_{2}-\bar{w}-t_{23}\right) x_{32}+\left(p_{3}-\bar{w}\right) x_{33} .
\end{aligned}
$$

Because of the cost-disadvantage for the unionised firm, and the potential differences in trade costs between different countries, the model permits three alternative trade regimes, endogenously determined by the union's optimal wage setting strategies. Since the trade union is assumed to be equally concerned about both wages and employment there is a fundamental trade-off in deciding upon the optimal wage demand. The firm will find it profitable to serve a given export market only if the sum of production costs and trade costs is small enough for exports to yield a positive profit contribution. Consequently, the higher level of employment associated with export production can only be obtained at a certain cost for the trade union, namely by accepting a wage that is low enough for export production to be profitable for the firm. Obviously, the higher is the trade costs, the lower is the wage level necessary to induce exports.

If the trade costs associated with exports to countries 2 and 3 are sufficiently low, the union may optimally set a wage that is low enough for intra-industry trade to occur between all three markets. In this case, denoted Regime A, the optimal wage is given by ${ }^{5}$

$$
\begin{aligned}
w_{1}^{\mathrm{A}} & =\arg \max \left\{U=\left(w_{1}-\bar{w}\right)\left(x_{11}+x_{12}+x_{13}\right)\right\} \\
& =\frac{1}{6}+\frac{1}{9}\left(t_{23}-t_{12}-t_{13}\right) .
\end{aligned}
$$

If the difference between $t_{12}$ and $t_{13}$ is sufficiently large, it may be optimal for the union to set a wage that prohibits exports to the country with highest trade costs. Assuming $t_{12}<t_{13}$, the optimal wage in this regime, denoted Regime $\mathrm{B}$, is given by

$$
\begin{aligned}
w_{1}^{\mathrm{B}} & =\arg \max \left\{U=\left(w_{1}-\bar{w}\right)\left(x_{11}+x_{12}\right)\right\} \\
& =\frac{1}{6}+\frac{1}{12}\left(t_{23}+t_{13}-2 t_{12}\right) .
\end{aligned}
$$

Finally, if both $t_{12}$ and $t_{13}$ are sufficiently high, the union may optimally set a wage that induces firm 1 to serve only its home market. We denote this as Regime C. The optimal wage level is given by

\footnotetext{
${ }^{5}$ A PDF document containing the underlying derivations of all the optimal wage levels reported in this section can be downloaded from the IJIO Editorial Office website.
} 


$$
\begin{aligned}
w_{1}^{\mathrm{C}} & =\arg \max \left\{U=\left(w_{1}-\bar{w}\right) x_{11}\right\} \\
& =\frac{1}{6}\left(1+t_{12}+t_{13}\right) .
\end{aligned}
$$

The optimal choice of wage demand strategy for the trade union is based on a utility comparison of the alternative trade regimes. Using backwards induction, the union will choose the wage strategy that yields the highest utility in the corresponding equilibrium outcome. Naturally, this results in different trade patterns for different levels of trade costs.

\subsection{A merger between the non-unionised firms}

In the absence of plant-specific fixed costs, the dominant strategy for the merged entity is always to retain both production plants post-merger, and serve its respective 'home markets', i.e. markets 2 and 3, by local production. Thus, by merging, the non-unionised firms are able to serve two markets without incurring any trade cost outlays. This is the standard 'tariff jumping' argument for establishing a multinational firm. Furthermore, the merged firm will be able to choose the plant from which to supply market 1 in a way that minimises total outlays on trade costs. Assuming $t_{12}<t_{13}$, the merged firm solves the following problem in the Cournot game: ${ }^{6}$

$$
\max _{x_{\mathrm{m} 1}, x_{\mathrm{m} 2}, x_{\mathrm{m} 3}} \pi_{\mathrm{m}}=\left(p_{1}-\bar{w}-t_{12}\right) x_{\mathrm{m} 1}+\left(p_{2}-\bar{w}\right) x_{\mathrm{m} 2}+\left(p_{3}-\bar{w}\right) x_{\mathrm{m} 3} .
$$

As in the decentralised structure, trade patterns are endogenously determined by the optimal wage strategy of the union. Since the mechanisms underlying the optimal choice of wage demand are identical in $M_{0}$ and $M_{2+3}$, the wage expressions are presented summarily, using the previously established notation:

$$
\begin{aligned}
& w_{1}^{\mathrm{A}}=\frac{1}{4}-\frac{1}{12}\left(t_{12}+2 t_{13}\right), \\
& w_{1}^{\mathrm{B}}=\frac{1}{4}-\frac{1}{8} t_{12}, \\
& w_{1}^{\mathrm{C}}=\frac{1}{4}+\frac{1}{4} t_{12} .
\end{aligned}
$$

Comparing the wage outcomes of $M_{0}$ and $M_{2+3}$, there are two aspects of interest. Firstly, it can be shown that the prohibitive levels of trade costs are higher in $M_{2+3}$. This is quite intuitive. A merger implies that the degree of competition in each separate market is lower. This means that the profitability of export production increases for the unionised firm. Thus, for each level of trade costs, firm 1 can afford higher production costs without having to refrain from exports. This obviously makes export production more attractive for the trade union, since

\footnotetext{
${ }^{6}$ Subscript ' $m$ ' refers to the merged firm.
} 
the employment gain can be obtained at a lower cost, in terms of wage reductions. Consequently, a merger between non-unionised firms implies an expansion of Regime A in our model.

Secondly, regarding within-regime comparisons, it is apparent that wages are higher in $M_{2+3}$. This is easily seen by a pair-wise comparison of (3)-(6), (4)-(7) and (5)-(8). Again, the intuition is relatively straightforward: due to quantities being strategic substitutes in the Cournot model, the unionised firm will optimally respond to a merger between non-unionised firms by increasing its output in all markets. The trade union, having preferences for both employment and wages, will then capitalise on the firm's improved competitive position by increasing wages. Thus, a merger between non-unionised firms in an international oligopoly is beneficial for unionised workers.

\subsection{A merger involving the unionised firm}

This is a market structure consisting of two different ownership structures, $M_{1+2}$ and $M_{1+3}$, which may yield different outcomes with respect to trade patterns, depending on the trade cost structure. We can, however, capture all possibilities by focusing attention on only one of the ownership structures.

Consider a merger between firms 1 and 2. There are now potentially three different trade regimes to consider. Assume first that $t_{13} \geqslant t_{23}$. There are now three possible motivations for such a merger. Firstly, the standard 'tariff jumping' argument applies: total outlays on trade costs can be reduced by serving markets 1 and 2 from the local production plants only. Secondly, since $w_{1} \geqslant \bar{w}$ and $t_{13} \geqslant t_{23}$, the merged firm's export market (market 3 ) can be served entirely from production in country 2, at the competitive wage level. However, such a merger could also function as a disciplinary device towards the trade union. In principle, there are two alternative ways for the merged firm to serve market 1 . It could be served by local production; this implies a saving of trade costs, but possibly at the expense of higher production costs, because of the unionised labour market. Alternatively, it could be served by production in country 2 . Thus, the wage setting of the union will be constrained by the merged firm's threat to move the entire production to the low-cost country. More specifically, a union wage in excess of $\bar{w}+t_{12}$ implies that market 1 can be served by the merged firm at a lower cost by shipping the good from country 2. Subsequently, the union is facing the following problem:

$$
\max _{w_{1}} U=\left(w_{1}-\bar{w}\right) x_{\mathrm{m} 1} \text { subject to } w_{1} \leqslant \bar{w}+t_{12} .
$$

Since the union will never set a wage in excess of $\bar{w}+t$, the merged firm solves the following problem at stage 2 of the game:

$$
\max _{x_{\mathrm{m} 1}, x_{\mathrm{m} 2}, x_{\mathrm{m} 3}} \pi_{\mathrm{m}}=\left(p_{1}-w_{1}\right) x_{\mathrm{m} 1}+\left(p_{2}-\bar{w}\right) x_{\mathrm{m} 2}+\left(p_{3}-\bar{w}-t_{23}\right) x_{\mathrm{m} 3} .
$$


Using the first-order conditions from profit maximisation, we find the optimal unconstrained wage in this regime, denoted Regime I, to be

$$
w_{1}^{\mathrm{I}}=\frac{1}{4}\left(1+t_{13}\right) \text {. }
$$

Consequently, wage setting is constrained if $t_{12} \leqslant \frac{1}{4}\left(1+t_{13}\right)$. We see that the effect of the merger as a union disciplinary device is crucially dependent on the sizes of trade costs, both in absolute and relative terms. The higher the trade costs between the home markets of the merger participants, the more expensive it is for the merged firm to carry out the threat of moving all production to the low-cost country.

Now consider the case where $t_{13}<t_{23}$. In this case it is not obvious that the merged firm will choose to serve market 3 from the country with the lowest production costs. More specifically, if the difference in production costs is lower than the difference in trade costs the merged firm will optimally choose plant 1 for export production. If this is the case, then the profit maximisation problem of the merged firm is now

$$
\max _{x_{\mathrm{m} 1}, x_{\mathrm{m} 2}, x_{\mathrm{m} 3}} \pi_{\mathrm{m}}=\left(p_{1}-w_{1}\right) x_{\mathrm{m} 1}+\left(p_{2}-\bar{w}\right) x_{\mathrm{m} 2}+\left(p_{3}-w_{1}-t_{13}\right) x_{\mathrm{m} 3} .
$$

Given this, at stage 1 of the game the trade union sets

$$
\begin{array}{ll} 
& w_{1}=\arg \max \left\{U=\left(w_{1}-\bar{w}\right)\left(x_{\mathrm{m} 1}+x_{\mathrm{m} 3}\right)\right\}, \\
\text { subject to } & w_{1} \leqslant \bar{w}+t_{12}, \\
& w_{1} \leqslant \bar{w}+t_{23}-t_{13} .
\end{array}
$$

The optimal unconstrained wage in this regime, denoted Regime II, is given by

$$
w_{1}^{\mathrm{II}}=\frac{1}{4}-\frac{1}{8} t_{13} .
$$

The last possible trade regime may occur if $t_{13}<t_{23}$ and $t_{12}$ is sufficiently low, so that the first constraint in (11) is binding. It may then be optimal for the trade union to set a wage that is low enough to keep the export production for market 3 in country 1 , but not low enough to prevent production for the home market being shifted to country 2 . We call this Regime III. In this case the merged firm solves the following problem:

$$
\max _{x_{\mathrm{m} 1}, x_{\mathrm{m} 2}, x_{\mathrm{m} 3}} \pi_{\mathrm{m}}=\left(p_{1}-\bar{w}-t_{12}\right) x_{\mathrm{m} 1}+\left(p_{2}-\bar{w}\right) x_{\mathrm{m} 2}+\left(p_{3}-w_{1}-t_{13}\right) x_{\mathrm{m} 3} .
$$

The union's problem is then to set

$$
\begin{array}{ll} 
& w_{1}=\arg \max \left\{U=\left(w_{1}-\bar{w}\right) x_{\mathrm{m} 3}\right\}, \\
\text { subject to } & w_{1} \leqslant \bar{w}+t_{23}-t_{13},
\end{array}
$$

which yields an optimal unconstrained wage

$$
w_{1}^{\mathrm{III}}=\frac{1}{4}-\frac{1}{2} t_{13} \text {. }
$$


As this subsection fully demonstrates, a merger involving the unionised firm may have vastly different effects on union wages, depending on the trade cost structure of the industry. A main observation, though, is that sufficiently small trade costs between the home markets of the merger participants turns the merger into an effective disciplinary device against the trade union. If trade costs in general are higher, the union is better protected against threats to move production abroad, and has a freer position to use its power to induce the most preferred trade regime, from the viewpoint of unionised workers.

We will look more closely into the wage responses of a merger in Section 5, when making further assumptions about the trade cost structure of the industry.

\section{Endogenous merger formation}

In order to make some predictions about merger formation in this model, we will make use of an approach developed by Horn and Persson (2001a), which treats the merger process as a cooperative game of coalition formation, where the players are free to communicate and write binding contracts.

Without going into details about the theoretical foundations, the approach involves a comparison of any two possible ownership structures $M_{i}$ and $M_{j}$, where $M_{i}$ is said to dominate $M_{j}\left(M_{i}\right.$ dom $\left.M_{j}\right)$ if the combined profits of the decisive group of owners are larger in $M_{i}$ than in $M_{j}$. The decisive group of owners are the owners that are expected to be able to influence whether $M_{i}$ will be formed instead of $M_{j}$, and vice versa. We do not allow payments between coalitions, so owners belonging to identical coalitions in the two structures cannot affect whether $M_{j}$ will be formed instead of $M_{i}$, but all remaining owners can influence this choice and are thus decisive.

Consider the ownership structures $M_{0}$ and $M_{1+2}$. In this case, owner 3 stands alone in both structures, so the decisive owners are the merger participants in $M_{1+2}$, i.e. owners 1 and 2 . Now consider instead $M_{1+2}$ and $M_{2+3}$. For $M_{1+2}$ to dominate $M_{2+3}$ it is not enough that owners 1 and 2 prefer $M_{1+2}$ over $M_{2+3}$. If owner 3 is adversely affected by the formation of $M_{1+2}$, this owner may want to persuade owner 2 to form $M_{2+3}$ instead, by offering a large share of the surplus in this structure. Thus, all three owners are decisive, and the dominance relation is determined by a comparison of total industry profits in the two ownership structures.

Finally, the solution concept is the core. Those structures that are in the core (i.e. the structures that are undominated) are defined as Equilibrium Ownership Structures (EOS).

\footnotetext{
${ }^{7}$ See Horn and Persson (2001a) for a formal definition of decisive owners.
} 


\section{Equilibrium ownership structure when the trade cost structure is symmetric}

In this section we consider the symmetric trade cost structure, where $t_{i j}=t$ for all $i$ and $j$. In other words, the cost of shipping a unit of the commodity between two countries is the same, irrespective of which two countries we consider. This assumption considerably decreases the number of potential trade regimes within each possible market structure.

Let us first consider $M_{0}$ and $M_{2+3}$. From the viewpoint of the unionised firm, since $t_{12}=t_{13}$ it is obvious that any wage level that makes exports to market 2 profitable also makes it profitable to compete in market 3. Consequently, the set of parameter values defining Regime $\mathrm{B}$ is empty. Setting $t_{12}=t_{13}=t_{23}=t$, a comparison of the relevant utility expressions (reported in Appendix A) reveals that the prohibitive level of trade costs, $t^{*}$, above which exports are unprofitable for the unionised firm, is $t^{*}=0.23$ in $M_{0}$ and $t^{*}=0.27$ in $M_{2+3}$. From (3), (5), (6) and (8) we find the resulting optimal union wages in these ownership structures to be

$$
\begin{aligned}
& w_{1}\left(M_{0}\right)= \begin{cases}\frac{1}{6}-\frac{1}{9} t, & \text { if } t \leqslant 0.23 \\
\frac{1}{6}(1+2 t), & \text { if } t>0.23\end{cases} \\
& w_{1}\left(M_{2+3}\right)= \begin{cases}\frac{1}{4}(1-t), & \text { if } t \leqslant 0.27, \\
\frac{1}{4}(1+t), & \text { if } t>0.27 .\end{cases}
\end{aligned}
$$

Considering $M_{1+2}$ and $M_{1+3}$, these ownership structures are now completely symmetric. Furthermore, because of trade cost symmetries, the only possible trade regime in this market structure is Regime I, in which the unionised firm produces only for its home market.

At this stage of the analysis, a closer look at the wage response to a merger involving the unionised firm is worthwhile. From (10) we find that the optimal wage in $M_{1+2}$ is given by

$$
w_{1}\left(M_{1+2}\right)= \begin{cases}t, & \text { if } t \leqslant \frac{1}{3}, \\ \frac{1}{4}(1+t), & \text { if } t>\frac{1}{3} .\end{cases}
$$

We see that the union wage is monotonically increasing in $t$, reflecting the role of trade costs as a source of protection for unionised workers. Furthermore, if we make a comparison with wages in Regime A of the decentralised structure, from (15), we find that wages are higher in $M_{1+2}$ than in $M_{0}$ if $t>0.15$. Comparing with Regime $\mathrm{C}$ in $M_{0}$, wages are higher in $M_{1+2}$ if $t>1 / 4$. In other words, if trade costs are not too low, a merger involving the unionised firm will actually raise the cost of serving market 1 for the merger participants. This is not immediately obvious, although the economic intuition is clearly traceable. The reason is that the merger has two effects on union wage setting that move in opposite directions. In 
addition to the aforementioned disciplinary effect, the merger also implies that the trade union no longer has any incentive to keep wages down in order to promote export production, since it is always more profitable for the merged firm to serve its export market from the low-cost country. When trade costs are sufficiently high, the second effect will dominate, resulting in higher union wages as a response to the merger.

Having identified the potential trade regimes in each possible market structure, we are now able to make predictions about the equilibrium ownership structure of the industry. As a benchmark for comparison, let us first briefly consider the special case of competitive labour markets in all countries, i.e. $w_{i}=\bar{w}$ for all $i$.

Lemma 1. $\exists \underline{t}>0$ such that a merger between any two firms is EOS if $t>\underline{t}$.

Proof. In this completely symmetric version of the model, there are only two possible market structures: merger and no merger. Thus, a merger is EOS if a merger between any two firms is profitable for the merger participants. Using equilibrium profit expressions (A.1) and (A.2) given in Appendix A, we find that this is the case if $t>\underline{t}=1 / 10$.

In light of the existing merger literature, this is an obvious result. When trade costs are zero, each market is characterised by Cournot competition between firms with identical cost functions. From the now famous result of Salant et al. (1983) we know that a merger between two out of three firms is unprofitable in such circumstances, due to the aggressive response from the non-merging firm. As trade costs increase, though, the 'tariff jumping' argument implies that total outlays on trade costs can be reduced by forming a multinational firm. Thus, if trade costs are sufficiently high, above $\underline{t}$, this effect dominates, and a merger is profitable for the participants.

We know turn to the main model, in which firm 1 is unionised. From a payoff comparison of the different market structures, the following proposition can be stated:

Proposition 1. $\exists \hat{t}>0$ such that $M_{1+2}$ or $M_{1+3}$ is EOS if $t \in(0, \hat{t})$ and $M_{2+3}$ is EOS if $t>\hat{t}$.

Proof. For our purposes, $M_{1+2}$ and $M_{1+3}$ are identical ownership structures. Consider therefore $M_{1+2}$. When comparing $M_{1+2}$ and $M_{0}$, the decisive group of owners consists of the merger participants in $M_{1+2}$. Setting $t_{12}=t_{13}=t_{23}=t$ in the relevant profit expressions reported in Appendix A, we find that $\pi_{\mathrm{m}}\left(M_{1+2}\right)>$ $\sum_{i=1}^{2} \pi_{i}\left(M_{0}\right)$, implying $M_{1+2}$ dom $M_{0}$, if $t<0.17$. For $t>0.17$ the dominance relation is reversed. Likewise, when comparing $M_{2+3}$ and $M_{0}$, the decisive owners are the merger participants in $M_{2+3}$. In this case we find that $\pi_{\mathrm{m}}\left(M_{2+3}\right)>$ 
$\sum_{i=2}^{3} \pi_{i}\left(M_{0}\right)$, implying $M_{2+3}$ dom $M_{0}$, for all $t$. When comparing $M_{1+2}$ and $M_{2+3}$, all three owners are decisive. In this case we have that $\sum_{i=1}^{3} \pi_{i}\left(M_{1+2}\right)>$ $\sum_{i=1}^{3} \pi_{i}\left(M_{2+3}\right)$, implying $M_{1+2} \operatorname{dom} M_{2+3}$, if $t<0.12$. For $t>0.12$ the dominance relation is reversed. Hence, $M_{1+2}$ is undominated if $t<0.12$ and $M_{2+3}$ is undominated if $t \geqslant 0.12$.

A non-trivial observation is the existence of an equilibrium ownership structure for all levels of trade costs. Furthermore, the equilibrium ownership structure always involves some type of merger.

From the proof of Proposition 1, we see that a merger between non-unionised firms is profitable for the merger participants, i.e. $M_{2+3}$ dom $M_{0}$, for all $t$. Note the contrast in results compared to the benchmark (Lemma 1), in which a merger is not profitable for low levels of trade costs. In a Cournot oligopoly we know that merger profitability depends on how aggressively the non-participants respond to the merger, and, if products are homogenous, a sufficient degree of cost saving is needed to make a merger between two firms profitable. In the present model, considering the market structure $M_{2+3}$, the non-participant is unionised, and its production costs are thus affected by the merger. Ceteris paribus, a merger between non-unionised firms improves the competitive position of the nonparticipant. The trade union optimally responds to this change in market structure by increasing its wage demand. This increases the cost disadvantage of the unionised firm, making its response to the merger less aggressive than it would have been if wages were exogenous. Due to this cost-raising effect, a merger between the non-unionised firms is profitable even for low levels of $t$.

A merger involving the unionised firm is profitable for the merger participants, i.e. $M_{1+2}$ dom $M_{0}$, if trade costs are sufficiently low, $t<0.17$. In this case, the union is in a weak position strategically, and merging with a low-cost firm implies a considerable cost saving for the merged entity in the form of both saved trade costs and lower union wages. For higher levels of trade costs, though, the union is provided with a stronger protection from the threat of moving production abroad, implying that merger profitability is decreasing in $t$. Indeed, for $t \in(0.15,0.23)$ or $t>0.25$, the union's wage setting incentives are such that a merger involving the unionised firm will lead to higher wages. For $t>0.17$ the positive effect of saved trade costs is more than outweighed by the combined negative effect of higher wages and an aggressive response from the non-merging firm, making a merger with the unionised firm unprofitable.

When the fully decentralised ownership structure is dominated by both types of merger, the EOS is determined by a comparison of total industry profits. For low levels of trade costs, a merger involving the unionised firm is the equilibrium ownership structure. When $t$ is low, union workers are poorly protected by trade costs, and a merger with a low-cost firm is an effective way to reduce union rents, and thereby increase industry profits. Due to this effect, a merger involving the unionised firm yields a larger contribution in terms of total industry profits. 
However, for higher levels of trade costs, $t>0.12$, a merger between the non-unionised firms is the equilibrium ownership structure.

\subsection{Trade liberalisation and union wages}

By allowing for endogenous merger formation in a model of international oligopoly with unionised and non-unionised firms, the effect of trade liberalisation on union wages will naturally differ from the more traditional models of this kind. In these types of models it seems reasonable to interpret trade liberalisation, or economic integration, as a (marginal) reduction of trade costs. ${ }^{8}$ Considering the fully decentralised structure as a benchmark, we can state the following lemma.

\section{Lemma 2.}

$$
\frac{\partial w_{1}\left(M_{0}\right)}{\partial t}<(>) 0 \text { if } t<(>) t^{*}\left(M_{0}\right)
$$

Proof. Setting $t_{12}=t_{13}=t_{23}=t$, the proof follows immediately from (15).

If trade costs are initially relatively low, $t<t^{*}\left(M_{0}\right)=0.23$, we have a Naylortype situation, in which a reduction in trade costs would lead to higher wages. Although our model setup is somewhat different from Naylor (1998), the general message is the same: in an international oligopoly, if trade costs are initially low enough for export production to be profitable for a unionised firm, a further reduction of trade costs will result in higher union wages. The reason is that a reduction in $t$ will lead to an increased degree of competition both in the home market and in the export market(s), implying that the total output of the unionised firm goes up. A union with preferences for both employment and wages will prefer to convert some of this employment increase into higher wages.

If, on the other hand, trade costs are initially relatively high, $t>t^{*}\left(M_{0}\right)$, results are reversed. In this case, export production is not profitable for the high-cost firm, and a marginal reduction of trade costs implies a higher degree of import competition in the unionised country. In order to soften the subsequent reduction in employment, the trade union optimally responds by reducing its wage demands.

Let equilibrium wages in our model with endogenous merger formation be denoted $w^{*}$. We have already seen that a merger between the non-unionised firms leads to an increase in union wages within each trade regime, and that a merger involving the unionised firm leads to an increase in wages if $t \in(0.15,0.23)$ or

\footnotetext{
${ }^{8}$ In line with our interpretation of trade costs, trade liberalisation should be thought of as any measures taken to reduce the costs of trade, including reduced tariffs, improved quality of infrastructure or reduced bureaucratic barriers to trade.
} 
$t>0.25$. Regarding the effect on union wages of trade liberalisation, the following proposition can be stated:

Proposition 2. $\partial w^{*} / \partial t>0$ if $t<\hat{t}, \partial w^{*} / \partial t<0$ if $t \in\left(\hat{t}, t^{*}\left(M_{2+3}\right)\right)$ and $\partial w^{*} / \partial t>$ 0 if $t>t^{*}\left(M_{2+3}\right)$.

Proof. Using Proposition 2, the result follows immediately from (16) and (17).

A merger between the non-unionised firms is the EOS for $t>\hat{t}$, and the mechanisms underlying the union's response to trade liberalisation are similar to the model without merger. Trade liberalisation leads to an increase (decrease) in union wages if $t$ is initially below (above) the prohibitive level $t *\left(M_{2+3}\right)=0.27$.

However, for low levels of trade costs the model predicts that the unionised firm will merge, causing a downward pressure on union wages. For $t<\hat{t}$ union wage setting is constrained, implying that a reduction in trade costs forces the union to lower its wage demands. Thus, for $t<\hat{t}$, trade liberalisation leads to a decrease in union wages. The results are illustrated in Fig. 1.

The model is rather stylised, so one should interpret the results with some care. Nevertheless, the general implications of trade liberalisation for unionised labour predicted by the model are the following: for higher levels of trade costs there will be a tendency towards international merger between non-unionised firms, and this will clearly benefit unionised labour (and unionised firms), since international competition is reduced. For lower levels of $t$, however, unionised firms are 'vulnerable' to international mergers, because this type of merger is more effective as a disciplinary device towards union wage demands when trade costs are low. This is of course detrimental to union workers. If we look at union utility, it turns

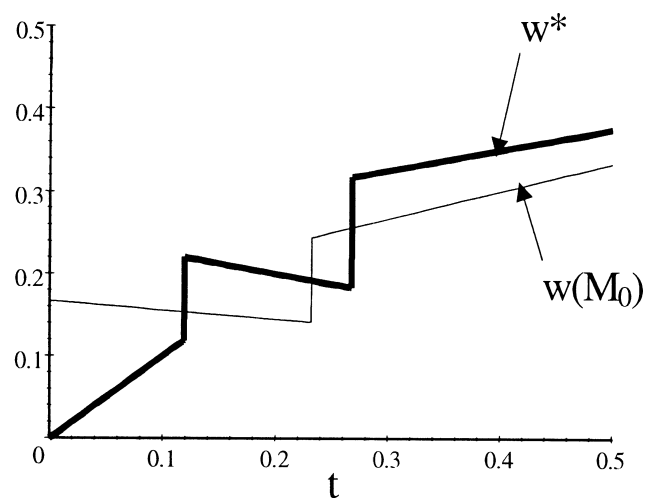

Fig. 1. Equilibrium union wages with (thick curve) and without (thin curve) endogenous merger formation. 
out that some intermediate level of protection, where $t$ is low enough to induce export production, but just high enough to prevent a merger, is the most preferable from the viewpoint of union workers.

\section{Concluding remarks}

Due to the complexities involved in capturing the strategic cross-country and cross-market interactions of firms in an international oligopoly industry, generality is hard to obtain. Nevertheless, even the rather stylised model of this paper produces some results and implications that are intuitively quite appealing.

The general idea explored in the paper is that, in an international oligopoly with unionised and non-unionised firms, different levels of trade costs create different incentives for international M\&A. In particular, the effects of mergers as a disciplinary device towards trade unions are highly dependent on how strongly unions are protected by trade costs. The present model suggests that, for low levels of trade costs, there will be a tendency towards international mergers involving unionised firms.

Due to the obvious importance of international M\&A as an empirical phenomenon, it is tempting to suggest that any comprehensive analysis of the effects of trade liberalisation on union wages in an international oligopoly industry should somehow include this possibility. Without claiming comprehensiveness, the present model nevertheless provides some interesting implications of trade liberalisation for unionised labour. For relatively high values of trade costs, the model predicts a tendency towards merger between non-unionised firms, which is beneficial for union workers, whereas low levels of trade costs make unionised firms increasingly 'vulnerable' to international M\&A.

Although international M\&A is an interesting phenomenon from a welfare point of view, a formal welfare analysis is deliberately omitted from the paper. One reason is that the dominance relation approach to endogenous merger formation does not specify how profits are divided between firms in the different ownership structures. This does not make the model perfectly suited for welfare analysis at country level, which is arguably the most interesting angle of incidence.

Finally, it is important to emphasise that the extent to which trade unions are 'protected' by trade costs is crucially dependent on how international product market competition is modelled. The literature suggests two main classes of models in this field: models of reciprocal trade, in the tradition of Brander (1981) and Brander and Krugman (1983), and 'third-market' models, in the tradition of Brander and Spencer (1985). 'Third-market' models are often interpreted as international competition in an integrated 'world market' (see, e.g., Corneo, 1995; Yang, 1995). If we use the second approach, and assume that the firms are competing in an integrated world market, possibly with associated trade costs, it can easily be shown that the EOS always involves a merger with the unionised 
firm. Thus, the existence of a 'home market' that to a certain degree is protected by trade costs is a necessary source of union power in our model.

\section{Acknowledgements}

I thank Kjell Erik Lommerud, Frode Meland, Robin A. Naylor, Steinar Vagstad and two anonymous referees for valuable comments. This research was partly undertaken during a visit to the Department of Economics at the University of Warwick, whose hospitality is gratefully acknowledged. I also thank Statoil for financial support through the Institute for Research in Economics and Business Administration (SNF).

\section{Appendix A. Equilibrium profits and union utility for symmetric trade costs}

Solving the two-stage game by backwards induction, and setting $t_{i, j}=t$, we derive the following expressions for equilibrium profits and union utility in each market structure.

Competitive labour markets

$M_{0}$ :

$$
\pi_{i}=\frac{1}{16}\left(1+4\left(t+t^{2}\right)\right)
$$

$M_{1+2}$ :

$$
\begin{aligned}
& \pi_{\mathrm{m}}=\frac{1}{9}\left(1+8 t-2 t^{2}\right), \\
& \pi_{3}=\frac{1}{9}\left(1-10 t+7 t^{2}\right) .
\end{aligned}
$$

Unionised labour market in country 1

$M_{0}$-Regime A:

$$
\begin{aligned}
& \pi_{1}=\frac{3}{64}-\frac{1}{16} t+\frac{11}{16} t^{2}, \\
& \pi_{2}=\pi_{3}=\frac{49}{192}-\frac{49}{144} t+\frac{337}{432} t^{2}, \\
& U=\frac{1}{144}(3-2 t)^{2} .
\end{aligned}
$$

$M_{0}$ - Regime C: 


$$
\begin{aligned}
& \pi_{1}=\frac{1}{64}(1+2 t)^{2}, \\
& \pi_{2}=\pi_{3}=\frac{59}{192}-\frac{67}{144} t+\frac{35}{48} t^{2}, \\
& U=\frac{1}{48}(1+2 t)^{2} .
\end{aligned}
$$

$M_{2+3}$-Regime A:

$$
\begin{aligned}
& \pi_{1}=\frac{1}{12}-\frac{1}{6} t+\frac{3}{4} t^{2}, \\
& \pi_{\mathrm{m}}=\frac{25}{48}-\frac{5}{24} t+\frac{11}{16} t^{2}, \\
& U=\frac{1}{8}(1-t)^{2} .
\end{aligned}
$$

$M_{2+3}$-Regime C:

$$
\begin{aligned}
& \pi_{1}=\frac{1}{36}(1+t)^{2}, \\
& \pi_{\mathrm{m}}=\frac{97}{144}-\frac{35}{72} t+\frac{49}{144} t^{2}, \\
& U=\frac{1}{24}(1+t)^{2} .
\end{aligned}
$$

$M_{1+2}$ :

$$
\begin{aligned}
& \pi_{\mathrm{m}}= \begin{cases}\frac{1}{3}-\frac{4}{9} t+\frac{2}{3} t^{2}, & \text { if } t<\frac{1}{3}, \\
\frac{1}{4}-\frac{1}{6} t+\frac{7}{12} t^{2}, & \text { if } t \geqslant \frac{1}{3},\end{cases} \\
& \pi_{3}= \begin{cases}\frac{1}{3}-\frac{4}{9} t+\frac{2}{3} t^{2}, & \text { if } t<\frac{1}{3}, \\
\frac{19}{48}-\frac{17}{24} t+\frac{43}{48} t^{2}, & \text { if } t \geqslant \frac{1}{3},\end{cases} \\
& U= \begin{cases}\frac{t}{3}(1-t), & \text { if } t<\frac{1}{3}, \\
\frac{1}{24}(1+t)^{2}, & \text { if } t \geqslant \frac{1}{3} .\end{cases}
\end{aligned}
$$

\section{References}

Brander, J.A., 1981. Intra-industry trade in identical commodities. Journal of International Economics $11,1-14$.

Brander, J.A., Krugman, P.R., 1983. A reciprocal dumping model of international trade. Journal of International Economics 15, 313-321.

Brander, J.A., Spencer, B.J., 1985. Export subsidies and market share rivalry. Journal of International Economics 18, 83-100.

Corneo, G., 1995. National wage bargaining in an internationally integrated product market. European Journal of Political Economy 11, 503-520.

Danthine, J.-P., Hunt, J., 1994. Wage bargaining structure, employment and economic integration. Economic Journal 104, 528-541.

Driffill, J., van der Ploeg, F., 1993. Monopoly unions and the liberalisation of international trade. Economic Journal 103, 379-385.

Driffill, J., van der Ploeg, F., 1995. Trade liberalisation with imperfect competition in goods and labour markets. Scandinavian Journal of Economics 97, 223-243.

Fisher, C.G., Wright, D., 1999. Unionized oligopoly and trade liberalization. Canadian Journal of Economics 32, 799-816. 
Head, K., Ries, J., 1997. International mergers and welfare under decentralized competition policy. Canadian Journal of Economics 30, 1104-1123.

Horn, H., Persson, L., 2001a. Endogenous mergers in concentrated markets. International Journal of Industrial Organisation 19, 1213-1244.

Horn, H., Persson, L., 2001b. The equilibrium ownership of an international oligopoly. Journal of International Economics 53, 307-333.

Huizinga, H., 1993. International market integration and union wage bargaining. Scandinavian Journal of Economics 97, 223-243.

Lommerud, K.E., Meland, F., Sørgard, L., 2001a. Unionized oligopoly, trade liberalization and location choice. Working Papers in Economics 17/01, University of Bergen.

Lommerud, K.E., Straume, O.R., Sørgard, L., 2001b. Merger profitability in unionized oligopoly. Discussion Paper No. 2738, Centre for Economic Policy Research.

Markusen, J.R., 1995. The boundaries of multinational enterprises and the theory of international trade. Journal of Economic Perspective 9, 169-189.

Naylor, R.A., 1998. International trade and economic integration when labour markets are generally unionised. European Economic Review 42, 1251-1267.

Rasmusen, E. (Ed.), 2001. Reading in Games and Information. Blackwell.

Salant, S., Switzer, S., Reynolds, R.J., 1983. Losses from horizontal merger: the effects of an exogenous change in industry structure on Cournot-Nash equilibrium. Quarterly Journal of Economics 98, 185-199.

Straume, O.R., 2002. Union collusion and intra-industry trade. International Journal of Industrial Organization 20, 631-652.

Sørensen, J.R., 1994. Market integration and imperfect competition in labor and product markets. Open Economic Review 5, 115-130.

UNCTAD, 2000. World Investment Report 2000: Overview. United Nations (www.unctad.org).

Yang, B.Z., 1995. Unionized oligopoly, labor-management cooperation, and international competitiveness. Journal of Economics 62, 33-53. 